University of Nebraska - Lincoln

DigitalCommons@University of Nebraska - Lincoln

\title{
Potential Citric Acid Exposure and Toxicity to Hawaiian Hoary Bats (Lasiurus cinereus semotus) Associated with Eleutherodactylus Frog Control
}

\author{
William C. Pitt
}

Gary W. Witmer

USDA-APHIS-Wildlife Services, gary.w.witmer@usda.gov

Susan M. Jojola

Hans Sin

Follow this and additional works at: https://digitalcommons.unl.edu/icwdm_usdanwrc

Part of the Life Sciences Commons

Pitt, William C.; Witmer, Gary W.; Jojola, Susan M.; and Sin, Hans, "Potential Citric Acid Exposure and Toxicity to Hawaiian Hoary Bats (Lasiurus cinereus semotus) Associated with Eleutherodactylus Frog Control" (2014). USDA National Wildlife Research Center - Staff Publications. 1407.

https://digitalcommons.unl.edu/icwdm_usdanwrc/1407

This Article is brought to you for free and open access by the U.S. Department of Agriculture: Animal and Plant Health Inspection Service at DigitalCommons@University of Nebraska - Lincoln. It has been accepted for inclusion in USDA National Wildlife Research Center - Staff Publications by an authorized administrator of DigitalCommons@University of Nebraska - Lincoln. 
Potential citric acid exposure and toxicity to Hawaiian hoary bats (Lasiurus cinereus semotus) associated with Eleutherodactylus frog control

\section{William C. Pitt, Gary W. Witmer, Susan M. Jojola \& Hans Sin}

\section{Ecotoxicology}

ISSN 0963-9292

Volume 23

Number 3

Ecotoxicology (2014) 23:429-436 DOI 10.1007/s10646-014-1208-8

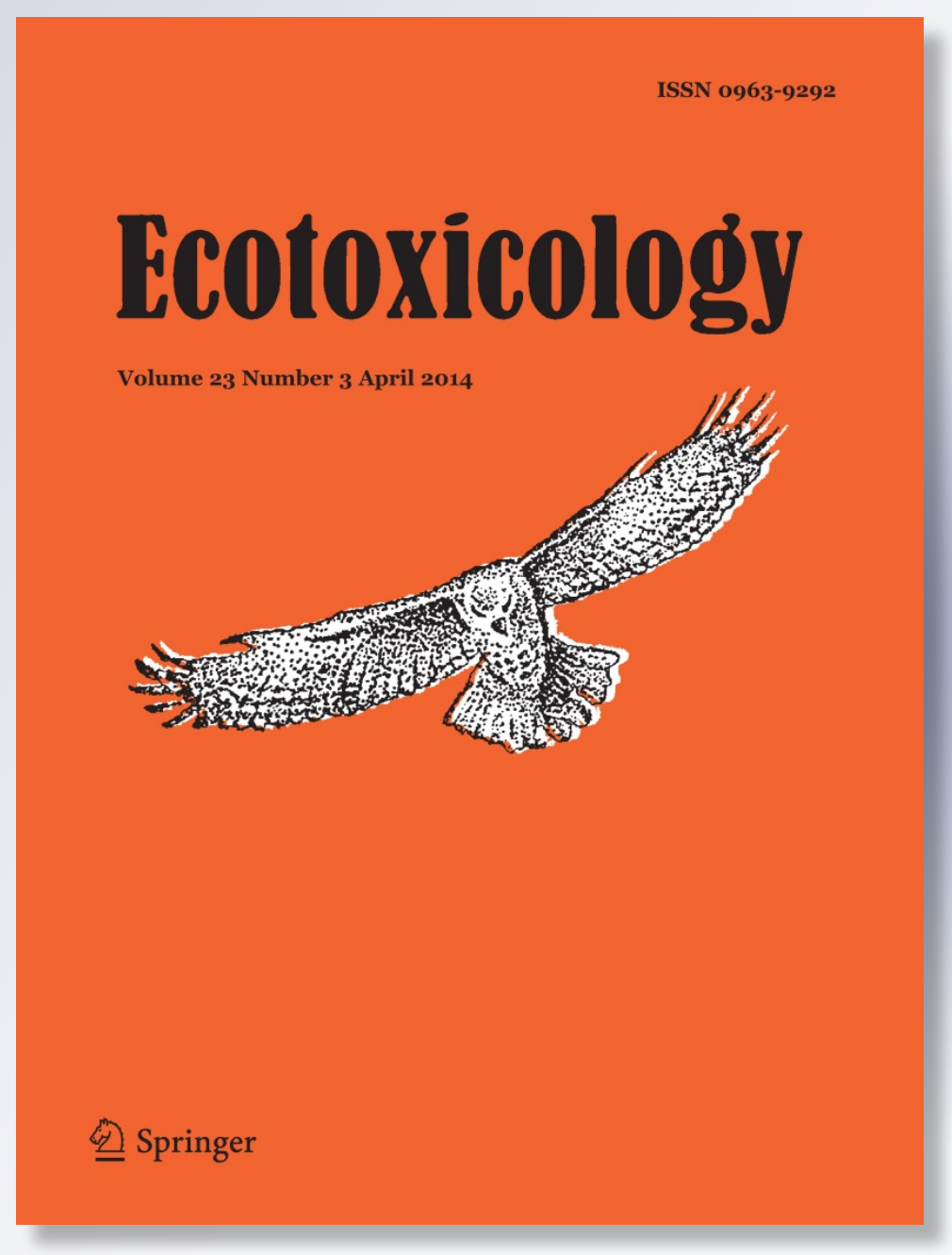

算 Springer 
Your article is protected by copyright and all rights are held exclusively by Springer Science+Business Media New York (outside the USA). This e-offprint is for personal use only and shall not be self-archived in electronic repositories. If you wish to self-archive your article, please use the accepted manuscript version for posting on your own website. You may further deposit the accepted manuscript version in any repository, provided it is only made publicly available 12 months after official publication or later and provided acknowledgement is given to the original source of publication and a link is inserted to the published article on Springer's website. The link must be accompanied by the following text: "The final publication is available at link.springer.com". 


\title{
Potential citric acid exposure and toxicity to Hawaiian hoary bats (Lasiurus cinereus semotus) associated with Eleutherodactylus frog control
}

\author{
William C. Pitt • Gary W. Witmer • \\ Susan M. Jojola $\cdot$ Hans Sin
}

Accepted: 28 January 2014/Published online: 14 February 2014

(C) Springer Science+Business Media New York (outside the USA) 2014

\begin{abstract}
We examined potential exposure of Hawaiian hoary bats (Lasiurus cinereus semotus) to citric acid, a minimum risk pesticide registered for control of invasive Eleutherodactylus frog populations. Hoary bats are nocturnal insectivores that roost solitarily in foliage, federally listed as endangered, and are endemic to Hawaii. Oral ingestion during grooming of contaminated fur appears to be the principal route by which these bats might be exposed
\end{abstract}

\section{W. C. Pitt $(\square)$}

Hawaii Field Station, National Wildlife Research Center, Wildlife Services, Animal and Plant Health Inspection Service, U.S. Department of Agriculture, P.O. Box 10880, Hilo, HI 96721, USA

e-mail: will.pitt@aphis.usda.gov

G. W. Witmer

National Wildlife Research Center, Wildlife Services, Animal and Plant Health Inspection Service, U.S. Department of Agriculture, 4101 LaPorte Avenue, Fort Collins, CO 80521, USA

\section{S. M. Jojola}

National Wildlife Research Center, Fort Collins, CO, USA

Present Address:

S. M. Jojola

AFB International, 3 Research Park Drive, St. Charles,

MO 63304, USA

\section{H. Sin}

National Wildlife Research Center, Hilo, HI, USA

Present Address:

H. Sin

Hawaii Department of Land and Natural Resources, 66-1220A

Lalamilo Road, Kamuela, HI 96743, USA to citric acid. We made assessments of oral toxicity, citric acid consumption, retention of material on fur, and grooming using big brown bats (Eptesicus fuscus) as a surrogate species. We evaluated both ground application and aerial application of $16 \%$ solutions of citric acid during frog control operations. Absorbent bat effigies exposed to ground and aerial operational spray applications retained means of 1.54 and $0.02 \mathrm{~g}$, respectively, of dry citric acid, although retention by the effigies was much higher than bat carcasses drenched in citric acid solutions. A high dose delivered orally $(2,811 \mathrm{mg} / \mathrm{kg})$ was toxic to the big brown bats and emesis occurred in 1 bat dosed as low as the $759 \mathrm{mg} / \mathrm{kg}$ level. No effect was observed with the lower doses examined $(\leq 542 \mathrm{mg} / \mathrm{kg})$. Bats sprayed with $5 \mathrm{ml}$ of $16 \%$ (w/w) citric acid solution showed no evidence of intoxication. In field situations, it is unlikely that bats would be sprayed directly or ingest much citric acid retained by fur. Based on our observations, we believe Hawaiian hoary bats to be at very low risk from harmful exposure to a toxic dose of citric acid during frog control operations.

Keywords Hoary bat - Lasiurus cinereus semotus - Coqui frog - Eleutherodactylus coqui · Control · Risk · Citric acid $\cdot$ Hawaii

\begin{tabular}{|c|c|}
\hline \multicolumn{2}{|c|}{ Abbreviations } \\
\hline APHIS & Animal and Plant Health Inspection Service \\
\hline FIFRA & $\begin{array}{l}\text { Federal Insecticide Fungicide and } \\
\text { Rodenticide Act }\end{array}$ \\
\hline GRAS & Generally recognized as safe \\
\hline HDOA & Hawaii Department of Agriculture \\
\hline U. S. EPA & $\begin{array}{l}\text { United States Environmental Protection } \\
\text { Agency }\end{array}$ \\
\hline USFWS & United States Fish and Wildlife Service \\
\hline
\end{tabular}




\section{Introduction}

Two species of Eleutherodactylus frogs native to Caribbean areas have established populations in Hawaii, presumptively first through introductions in horticultural material and secondarily through inadvertent local transport or intentional anthropogenic movement to new areas (Kraus et al. 1999). Several hundred frog populations have been identified on the four largest Hawaiian IslandsHawaii, Oahu, Maui, and Kauai (Kraus and Campbell 2002; Pitt and Sin 2004; Pitt et al. 2012). Concerns with the establishment of frog populations range across the tourism and real estate industries (disruptive noise from loud frog calls, Kaiser and Burnett 2006; Beard et al. 2009), the landscape and floriculture industries (reduced profits and inter-island or export quarantines, along with the potential for infection of plants with diseases or parasites, Kraus and Campbell 2002; Kaiser and Burnett 2006), conservation of biodiversity (high density frog populations competing for food with endangered native bird species, Kraus et al. 1999), accidental or intentional export of frogs to fragile ecosystems on adjacent islands or mainland areas (Kraus et al. 1999; Campbell and Kraus 2002; Kraus and Campbell 2002), and regulatory changes related to pest control (Beard et al. 2009).

A variety of physical and chemical control methods have been investigated to allow land owners and government agencies to deal with expanding frog populations initially with the goal of eradication (Kraus and Campbell 2002), later with a focus on local problem management (Beard et al. 2009). Physical methods considered include barriers, hot water or vapor heat treatment, hand-capture or trapping, and habitat management (Beard et al. 2009). Chemicals examined included caffeine, hydrated lime, endosulfan, sodium and potassium bicarbonate and citric acid (Pitt and Sin 2004; Pitt et al. 2012). Although all of these chemicals had toxic effects in laboratory trials, only caffeine, hydrated lime (calcium hydroxide), and citric acid were developed as registered pesticides for spray applications (Campbell and Kraus 2002; USEPA 1992; HDOA 2002; Anon. 2005) and only citric acid was pursued to the point of full operational use (Beard et al. 2009). Citric acid is applied as a $16 \%$ spray or foliage drench to frog occupied areas (HDOA 2002; Pitt et al. 2012). The state and counties have developed various cooperative programs to loan commercial size power sprayers to individuals or groups at no cost. A second method, rarely used, is for aerial application using a helicopter and water drop-bucket, generally used to cover larger and more remote natural areas (Tuttle et al. 2008).

The endemic Hawaiian hoary bat (Lasiurus cinereus semotus) has iconic status as Hawaii's only native terrestrial mammal and is listed as endangered by both the state and federal governments (USFWS 1998). Hawaiian hoary bats are nocturnal, insectivorous, and roost solitarily in tree foliage (USFWS 1998). Jacobs (1996) found that Hawaiian hoary bats can be $45 \%$ smaller than their North American counterparts. Males average a mass of $14.1 \mathrm{~g}$ while females are larger with an average body mass of $17.9 \mathrm{~g}$. The pregnancy period for Hawaiian hoary bats lasts from April to June, birthing of young occurs in May or June, with lactation taking place from June to August, and post-lactation occurring from September to December (Menard 2001; USFWS 1998).

Hoary bats have been found in most habitats infested by tree frogs; citric acid applied to forests or other natural areas as well as landscaped or settled areas might result in exposure to hoary bats. Daytime applications would be most likely to result in bat exposure while they are in roost trees. Some bat species undergo diurnal torpor and seem in a dormant state and are not readily disturbed by activities occurring in the surrounding environment. Torpor has not been documented in Hawaiian hoary bats and whether bats would react and vacate areas being sprayed has not been studied. Chances of bat exposure to spray operations might also be higher during the summer pupping season when females are less mobile and their young are nonvolant.

Little ecological information is available for the Hawaii hoary bat subspecies (Shump and Shump 1982, Whitaker and Tomich 1983, Tomich 1986, USFWS 1998, Gorresen et al. 2013). The listing as "endangered" was based on presumed population declines, suspected habitat loss, and other potential threats inferred from mainland studies of other species. However, there have been no definitive studies of the abundance and population status of hoary bats in Hawaii (Jacobs 1999; Gorresen et al. 2013).

Because pesticide use and contaminants are often cited among the factors affecting endangered species and contributing to bat species declines in particular (Clark et al. 1978; Anon. 1991; USFWS 1998), we and our research colleagues were particularly cognizant of such concerns in developing frog control methods. Bats' fur acts as a barrier to the skin, reducing dermal exposure to contaminants. Thus, the main pathway that bats are likely exposed to chemical contaminants is by oral ingestion (Sample et al. 1997), including grooming. We were particularly concerned with this route of exposure since it has been a preferred method of delivering chiropteracides for control of bat populations (Barclay et al. 1980; Mitchell 1986). Whitaker and Tomich (1983) found generalization of the insectivorous diet by the Hawaiian subspecies of this species; Ratcliffe et al. (2003) reported that bats with insectivorous and frugivorous diets acquired taste-aversions to citric acid. Therefore, it is possible that Hawaiian hoary 
bats may avoid ingesting citric acid-contaminated water or insects and would not ingest material contaminating fur when grooming.

Citric acid has been listed as a GRAS (generally recognized as safe) non-regulated, minimum risk pesticide and is exempt from the registration requirements under Federal Insecticide Fungicide and Rodenticide Act by the U. S. Environmental Protection Agency (FIFRA section 25b, 40 CFR Section 152.25). Citric acid is easily degraded by micro-organisms in soil, natural waters, and sewage treatment systems (USEPA 1992). Thus, a number of generic data requirements could be waived in developing its use as a frog toxicant. Nonetheless the general public's and regulatory agencies' concerns with pesticide use in Hawaii's fragile environments led us to examine the environmental effects of citric acid use.

Here we report laboratory and field studies related to potential citric acid exposure and toxic effects on Hawaiian hoary bats. Our studies had five objectives: (1) determine toxicity levels of citric acid to bats, (2) determine the quantity of citric acid solution a bat would voluntarily consume, (3) determine effects of spraying citric acid solution on bats, (4) determine the amount of citric acid solution that could be potentially retained by bat fur, and (5) quantify the amount of citric acid Hawaiian hoary bats might encounter in actual ground and aerial spray operations.

\section{Materials and methods}

Study subjects

Big brown bats (Eptesicus fuscus) were used as a surrogate species for the Hawaiian hoary bat. Both species are insectivorous, similar in size (13-20 g) and belong to the family Vespertilionidae (Tomich 1986; Lollar and Schmidt-French 2002). Thirty-six wild big brown bats (26 females, 10 males) were captured locally in Fort Collins, Colorado, between 20 and 30 August 2007. Bats were individually marked with colored wing bands and grouphoused in plastic storage containers (6 bats/container) that were lined with fiberglass screen with cotton cloth covering. These transparent containers were $60 \mathrm{~cm}$ long, $40 \mathrm{~cm}$ wide, and $35 \mathrm{~cm}$ high. Bats were acclimated to feeding on meal worms placed ad libitum in a Petri dish in each container; two additional Petri dishes contained drinking water. Group cages were changed for cleaning weekly. Individual bats were randomly assigned to trials and treatment groups. All trials used individually-housed bats in smaller bins ( $35 \mathrm{~cm}$ long, $30 \mathrm{~cm}$ wide, and $30 \mathrm{~cm} \mathrm{high).}$ Animal rooms were maintained at a temperature of $22{ }^{\circ} \mathrm{C}$.
Oral toxicity

Citric acid (Sigma-Aldrich, St. Louis, MO; CAS Number 77-92-9) was reagent grade (99-100\% purity) and solutions were prepared weight to weight $(\mathrm{w} / \mathrm{w})$ rather than the weight/volume to mix spray solutions. We conducted these initial laboratory and oral toxicity trials using $16 \%$ and $8 \%$ citric acid solutions (w/w) to assess toxic effects (equivalent to $14.6 \%$ and $7.3 \%$ by the unadjusted $\mathrm{w} / \mathrm{v}$ method of preparation). Throughout the paper, to avoid confusion with the operationally used material, we refer to all solutions based on the equivalent $\mathrm{w} / \mathrm{v}$ concentrations.

We evaluated oral toxicity of citric acid solutions to bats by gavage by two methods: (1) holding the volume constant at $1 \mathrm{ml}$ and adjusting concentration, and (2) holding concentration constant and adjusting volume. The up-anddown method (Bruce 1985) was used, relying on single animal treatment, observation of symptoms for 2 days, then treating a second animal with either a higher or lower dose depending on the previous response. Planned doses were separated on a 1.4 geometric progression dose; doses were then recalculated to accurately reflect actual delivery of the active ingredient. Syringes were prepared by adding citric acid granules, inserting the plunger to the $1 \mathrm{ml}$ mark, adding water through the neck of the syringe via a needle, rocking to dissolve granules, then attaching an 18 gauge, $5.08 \mathrm{~cm}$ gavage needle. Only females were used for this trial, since in some species, they are more sensitive to toxic materials (Rispin et al. 2000).

Symptoms of intoxication varied considerably among individual bats. Minor responses observed included trembling, lethargy, hyperactivity, or gagging. Emesis or deaths were more consistent and observable symptoms; deaths or emesis, within $48 \mathrm{~h}$ after gavage, were chosen as decision responses to determine whether the dose for the next bat should be lower or higher. Emesis is an adverse physiological reaction that may protect an individual from a toxic substance by expelling it from the body. Bats were observed directly for the first hour after gavage, hourly for the next $6 \mathrm{~h}$, then every $4 \mathrm{~h}$ up to $24 \mathrm{~h}$. Periodic observations occurred from 24 to $48 \mathrm{~h}$ post-gavage.

We subsequently evaluated toxicity of only $14.6 \%$ (w/ v) citric acid solution by oral gavage and adjusted volumes. We used the same methods and geometric progression as in the first trial to determine treatment volumes. Individual doses were calculated proportionately to a $26 \mathrm{~g}$ bat (median bat weight) receiving a $0.50 \mathrm{ml}(0.019 \mathrm{ml} / \mathrm{kg})$ gavage. The $0.5 \mathrm{ml}$ dose was used as a starting point so the potential maximum volume needed would be less than $5 \%$ $(\mathrm{ml} / \mathrm{kg})$. Thus, a $35 \mathrm{~g}$ bat would receive $0.67 \mathrm{ml}$ of $14.6 \%$ citric acid solution. 


\section{Consumption}

Voluntary consumption of citric acid by bats was evaluated by assigning two bats each ( 7 female, 1 male) to treatment groups of 2.0, 7.3, or $14.6 \%$ citric acid solution offered in Petri dishes. A control group was offered water in Petri dishes. Petri dishes were refilled with $50 \mathrm{ml}$ of liquid every $24 \mathrm{~h}$ for 3 days and the trial was video recorded. Review of video footage suggested that some bats sampled the solution, but did not drink; therefore observations were terminated after 3 days.

We compared bat weights before and after the trial using a paired $t$ test.

\section{Grooming}

Effects of citric acid ingested by bats during grooming were examined by spraying bats over their entire body, including wing and tail membranes, with $5 \mathrm{ml}$ of either $14.6 \%$ citric acid solution $(\mathrm{n}=5)$ or with $5 \mathrm{ml}$ of distilled water $(\mathrm{n}=5)$, then placing them in their individual containers. Behavior was observed for $4 \mathrm{~h}$ afterward; food and water were available ad libitum. We recorded qualitative descriptions of observed behaviors.

\section{Retention}

Twenty euthanized bats were used to evaluate citric acid retention in fur after completion of earlier trials, excluding grooming. A paperclip was used to secure skin near the tail; a carcass was then held by the paperclip and the rostrum (to keep the mouth closed) and immersed in a $14.6 \%$ citric acid solution for 2-3 s. Each bat's weight was recorded before dipping in the solution. Carcasses were hung by the paperclips for either 2 or $30 \mathrm{~min}$, then weighed to determine liquid retention.

\section{Field assessment methods}

To determine potential bat exposure at spray sites, we placed bat effigies to facilitate measurement of citric acid absorption. The bat effigies were constructed of absorbent, pre-formed bundles of cotton batting $50 \mathrm{~mm}$ in length, utilizing readily available retail tampons (O.B. ${ }^{\circledR}$ Super, McNeil-PPC, Inc.) in order to standardize effigy size. To form effigies that approximated Hawaiian hoary bat volume (25 ml, C. Kishinami, B. P. Bishop Museum, pers. comm.), we soaked the tampons in water to obtain full expansion, then placed each effigy in a foil cup and dried in a convection oven at approximately $84{ }^{\circ} \mathrm{C}$ for at least $16 \mathrm{~h}$. Immediately after removal, we recorded the masses of the effigies, including the foil cups as tare. Effigies were kept in the foil containers and stored in a covered plastic container while in transport to and from the treatment sites.

At the ground treatment sites, we deployed 39 effigies at various heights above ground level (from 100 to $500 \mathrm{~cm}$ ) immediately before spraying of citric acid and 27 effigies in a nearby reference area (from 100 to $300 \mathrm{~cm}$ above ground). We similarly placed 25 effigies in the aerial spray area (at heights ranging from 120 to $500 \mathrm{~cm}$ above ground) and 5 in a reference area (effigies in the reference area were inadvertently exposed to spray and were discarded). We recovered effigies immediately after spraying and dried them as before for at least $16 \mathrm{~h}$. The mass of each effigy was recorded after drying and compared to the pre-treatment mass. The mean change in mass of effigies from reference plots $(0.01 \mathrm{~g})$ was used to correct the mass changes of the treatment effigies. The differences in mass before and after spraying represented the amounts of citric acid absorbed and were attributed to solid citric acid granules recovered on the dried effigies. We compared the amount of solution retained by effigies using a one-way ANOVA.

\section{Ground-spray application}

The ground-based applications were conducted at eight individual spray sites treated during May and June 2006. The sites ranged from residential properties to native forests (range 50-3,035 $\mathrm{m}^{2}$ ). All treatments occurred between 1600 and 2000 hours and were done with a $16 \%$ citric acid solution. Operators used $1.5 \mathrm{kl}$ gasoline-powered tanks with the adjustable nozzles attached to either a $3.8-\mathrm{cm}$ diameter fire hose or standard size garden hose. This method and citric acid concentration were the same as those used by commercial applicators. We measured the amount of solution applied and the area treated. The operator conducting the spraying varied between sites. Spray application rate $\left(\mathrm{kl}^{-\mathrm{ha}^{-1}}\right.$ of solution) varied greatly between sites. Of the eight sites, four received less than $19 \mathrm{kl}-\mathrm{ha}^{-1}$ of citric acid solution, two received between 19

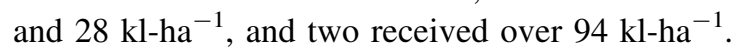

Aerial-spray application

The aerial spray applications took place at the Manuka State Park in the Kau District on the island of Hawaii in December 2006. Hawaii State Parks personnel conducted a substantial aerial citric acid spray operation for the control and containment of coqui frogs (Eleutherodactylus coqui). Approximately $58 \mathrm{kl}$ of $13 \%$ (w/v) citric acid were applied via helicopter and drop-bucket over 3 days, covering an area of $4.13 \mathrm{ha}$. We conducted our experiment on the third day of aerial operations, during which $21 \mathrm{kl}$ of citric acid solution were applied to 1.46 ha between 1100 and 1500 hours. The

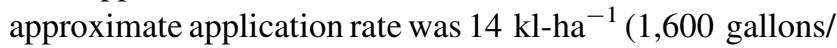


acre), delivered from an approximate height of $50 \mathrm{~m}$ above ground level.

\section{Results}

\section{Oral toxicity}

The amount of citric acid considered toxic to the bats, based on the adverse physiological reaction of emesis, was within the range of 542 and $759 \mathrm{mg} / \mathrm{kg}$. At the highest dose delivered, $7,361 \mathrm{mg} / \mathrm{kg}$, death of the bat occurred within 4 min. Emesis occurred in one of three bats dosed at $759 \mathrm{mg} / \mathrm{kg}$. No effects were observed at $542 \mathrm{mg} / \mathrm{kg}$, the lowest dose delivered. Most emesis occurred within the first hour after gavage, sometimes as soon as $3 \mathrm{~min}$. The volume of $14.6 \%$ citric acid solution estimated as toxic to the bats by ingestion, based on emesis, was between 0.14 and $0.26 \mathrm{ml}$. The first and highest dose, $0.57 \mathrm{ml}$, resulted in death of the bat within $4 \mathrm{~min}$. The lowest dose at $0.10 \mathrm{ml}$ did not result in emesis.

Grooming, citric acid consumption, and liquid retention

In grooming trials, bats treated with water were observed shaking (to release water from their fur) and grooming, including licking and scratching or combing with back feet or thumbs. Most bats sprayed with citric acid solution removed fur with their feet, probably because it became sticky and matted. Sticky fur that was pulled out was generally removed from the feet by licking. Some bats ate a few meal worms during the 4-h observation, but none were observed to drink. Emesis was not observed for any of the bats in these trials. As bats dried, fur appeared either combed or became thinner due to removal. None of the bats sprayed with distilled water were observed removing fur. Bats were monitored for a week following treatment; all survived in apparent good health. Additionally, bats gained a small amount of weight (about $1.5 \mathrm{~g}$ ) over the course of the trial. The starting average bat weight was $24.96 \mathrm{~g}( \pm 3.10 \mathrm{SD})$ while the average end bat weight was $26.53 \mathrm{~g}( \pm 3.97 \mathrm{SD})$. The starting and end weights were not significantly different $(t=1.25, P=0.2225)$.

The procedure used to attempt to estimate direct voluntary consumption of citric acid solutions was flawed in that animals became wet from walking in the open Petri dishes used to present the liquid. Review of video footage suggested that none of the bats drank the solution, although there were a few questionable instances. Results and observations generally paralleled those for the test on grooming in that bats appeared to avoid consumption of citric acid. Some bats, upon apparently licking the solution,

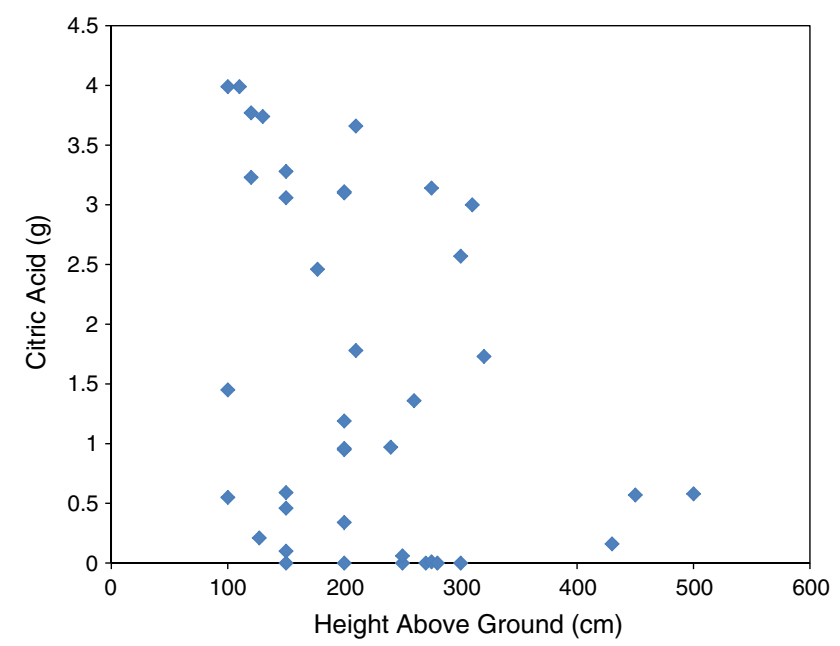

Fig. 1 Citric acid residues recovered from Hawaiian hoary bat effigies at ground application sites

heaved their head backward away from the solution and often quickly left the Petri dishes.

In examining retention of the citric acid solutions in bat fur, we found that bat carcasses retained a mean of $1.06 \mathrm{~g}$ $( \pm 0.20 \mathrm{SD})$ of citric acid solution after $2 \mathrm{~min}$ of drainage $(\mathrm{n}=10)$ and $0.45 \mathrm{~g}( \pm 0.11 \mathrm{SD})$ of citric acid solution after $30 \min (\mathrm{n}=10)$.

\section{Ground spray application}

The average citric acid load of all treatment bat effigies was $1.54 \mathrm{~g}( \pm 1.43 \mathrm{~g})$ (dry mass), but ranged widely from 0 to $3.99 \mathrm{~g}$. There appeared to be a decreasing trend in the amount of citric acid absorbed as the placement height increased but the differences were not significant among low, moderate, and high height classes $(\mathrm{F}=2.52, P=0.0948)$ (Fig. 1). When grouped by height, the effigies between 100 and $150 \mathrm{~cm}$ above ground level absorbed on average the most citric acid ( $2.03 \mathrm{~g}, \mathrm{n}=14)$. The average citric acid load of effigies placed between 151 and $250 \mathrm{~cm}$ above ground was $1.43 \mathrm{~g}(\mathrm{n}=13)$. Effigies placed higher than $250 \mathrm{~cm}$ above ground retained the least citric acid $(1.09 \mathrm{~g}, \mathrm{n}=12)$. When grouped by volume of citric acid solution applied, effigies at sites receiving $<28 \mathrm{kl}-\mathrm{ha}^{-1}$ of citric acid solution had an average citric acid load of $0.90 \mathrm{~g}(\mathrm{n}=24)$. Effigies at sites sprayed with more than $93.5 \mathrm{kl}^{-\mathrm{ha}^{-1}}$ averaged $2.75 \mathrm{~g}$ $(\mathrm{n}=13)$. This suggested a positive linear relationship between citric acid load and application rate.

Aerial spray application

The mean citric acid load of the treatment effigies was very low $(0.02 \mathrm{~g})$, although values ranged from 0 to $0.16 \mathrm{~g}$ (standard deviation 0.03). Here also, there was no apparent relationship between height above ground and citric acid 


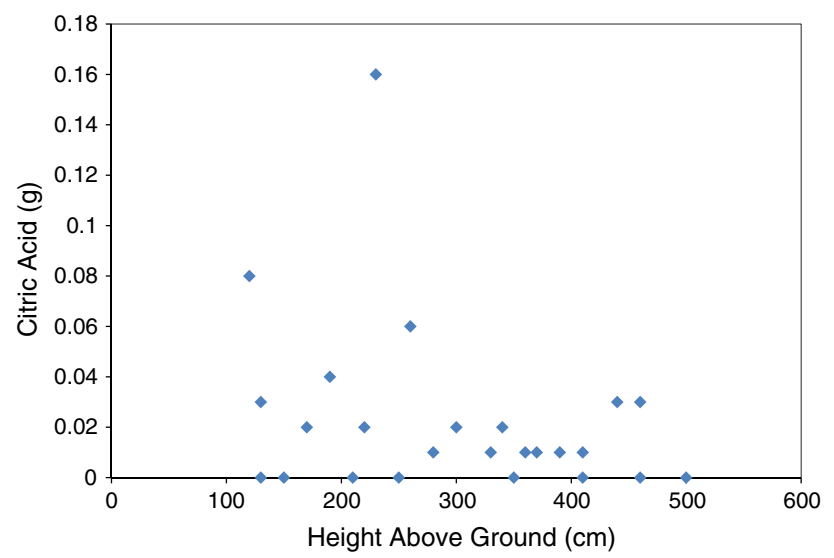

Fig. 2 Citric acid residues recovered from Hawaiian hoary bat effigies at aerial application sites

retained (Fig. 2). When grouped by height, the effigies placed between 100 and $199 \mathrm{~cm}$ above ground retained an average of $0.03 \mathrm{~g}$ of citric acid $(\mathrm{n}=6)$. The average citric acid load of effigies placed between 200 and $299 \mathrm{~cm}$ above ground was $0.04 \mathrm{~g}(\mathrm{n}=6)$. Effigies between 300 and $399 \mathrm{~cm}$ above ground received an average of $0.01 \mathrm{~g}$ of citric acid $(\mathrm{n}=7)$. Those $400 \mathrm{~cm}$ above ground or higher received an average of $0.01 \mathrm{~g}$ of citric acid $(n=6)$. The amount of citric acid retained by bat effigies did not vary significantly across height classes $(\mathrm{F}=0.76, P=0.4810)$. Spray volumes per unit area were substantially lower in the aerial applications compared with those at ground appli-

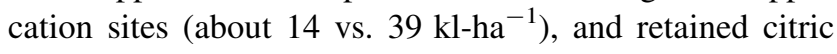
acid was, on average, about 75 times less.

\section{Discussion}

Spray applications of citric acid are quick and effective at killing invasive coqui frogs and controlling infestations, but the potential for exposure to Hawaiian hoary bats and of any conservation consequences have not been previously addressed. In oral gavage trials, bat toxicity gauged by death or emesis associated with administration of the $14.6 \%$ citric acid solutions used in frog control occurred between 0.14 and $0.26 \mathrm{ml}$, equivalent to $852-1,309 \mathrm{mg} / \mathrm{kg}$ of citric acid (based on a $26 \mathrm{~g}$ bat) or 20-38 $\mathrm{mg}$ of citric acid (Fig. 3). Further, using the minimum emetic dose or maximum tolerated dose provides a more conservative estimate of toxicity than using only death as an end point. The lowest dose that caused bat mortality was $2,811 \mathrm{mg} /$ $\mathrm{kg}$. Bats did not voluntarily consume measureable amounts of citric acid. Our video footage taken during treatment trials suggested bats could detect the adulterated solutions and probably would not drink citric acid contaminated

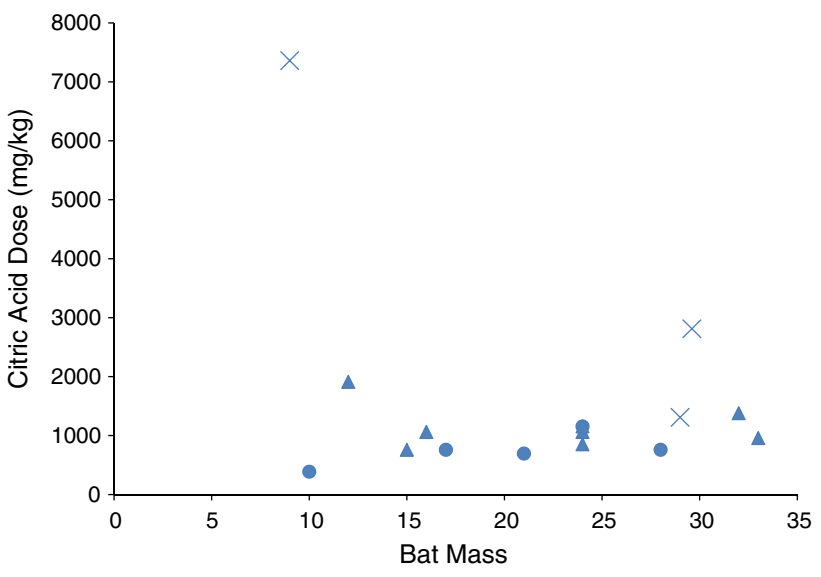

Fig. 3 The fate of bats dosed with a citric acid solution from trials with either a constant volume $(0.5 \mathrm{ml})$ or constant solution concentration $(16 \%)$. Bat response to each dose is designated as closed circle for bats with no observable effects, closed triangle where emesis was recorded, and times for bats that died

water pooled in operational areas. This interpretation is consistent with Ratcliffe's (2003) findings wherein bats with generalized diets acquired taste-aversions to citric acid.

Bats sprayed with $5 \mathrm{ml}$ of citric acid solution showed no evidence of intoxication. Five millilitres of $16 \%$ citric acid solution (w/w) would contain about $728 \mathrm{mg}$ of citric acid, but 2 min after application only $155 \mathrm{mg}$ of citric acid remained on the fur. However, bats physically removed the citric-acid coated fur with their feet; then licked the fur off of their feet. They did not ingest amounts of citric acid during this process that caused observable effects. In areas with frequent precipitation, rain could rinse much of the citric acid from bat fur, whether the bat was roosting or flying, rendering citric acid residues a non-concern.

The citric acid loads measured for bat effigies at groundbased application sites were highly variable but appeared to generally decrease with increasing height above ground level. At each site there were different spray operators applying the citric acid solution. Each spray operator had a different spray technique, influencing which areas of the foliage received the most citric acid solution. In all cases, the operators were focused on drenching the ground and understory. When the spray nozzles were pointed upward into the foliage, the spray streams tended to fan, increasing the likelihood of interception by foliage. Vegetation type could be a further determining factor of how much citric acid solution would penetrate through the foliage to roosting bats. It appears from our results, with higher variability of citric acid retention on effigies nearer the ground and from our observations of the ground spray application procedures, that bats would encounter less 
citric acid solution the higher they were roosting above ground. Although bats have been observed roosting close to the ground, Gorressen et al. (2013) reported that dayroosts generally occur in trees greater than five meters crown height. Our results were also consistent with the presumption that when greater volumes of solution were applied, the chances of bat exposure increased. The citric acid loads for all bat effigies in the aerial application were minimal, suggesting that bats would have very low risk for citric acid exposure during such operations. Furthermore, the amount of citric acid absorbed by the effigies greatly exceeded the potential amount that a bat's fur could absorb as observed in laboratory trials.

While citric acid is recognized as a mild skin irritant (rabbit-24 h, Sigma-Aldrich MSDS 4.0, 2010, http://www. sigmaaldrich.com/catalog/Display/MSDSContent.do, accessed July 7, 2011), dermal toxicity is not indicated. Furthermore, the fur and hair of mammals affords protection from direct skin contact, reducing dermal exposure to contaminants; thus the main pathway of mammal exposure to chemical contaminants is by oral ingestion (Sample et al. 1997). Therefore, the greatest concern would be that bats sprayed with citric acid will inadvertently ingest it while grooming. However, no toxic effects resulting from grooming contaminated fur were observed in this study. Rather, the primary potential impact identified in this study is from hair loss during grooming. The effect of hair loss on thermoregulation in the tropics and how long this effect would last is unknown. Additionally, the extra grooming may consume excessive energy and weaken the animal, and/or reduce the time spent foraging. The effect of hair loss may be greater on bats in nontropical areas and bats exposed to repeated citric acid applications may be at greater risk from hair loss or excessive grooming.

While the risk of exposure to citric acid at levels shown to cause signs of toxicity is very low for both ground and aerial spraying, there is still the potential for other, nontoxic, impacts to bats, so exposure to spray volumes high enough to coat a bat's fur should be avoided. This scenario is most likely to occur during ground-based treatments, when the applied volume is highest. To minimize the potential for exposure to bats, citric acid treatment planning should take into account the time of year to avoid exposure to lactating females and their young, set maximum spray heights, and train applicators to avoid spraying any area with excessive volume. We conclude that current frog control operations with citric acid, as already approved and conducted, pose little toxic threat to Hawaiian hoary bats because individuals would likely not be exposed to toxic doses of citric acid if inadvertently sprayed.

Acknowledgments We thank Patrick Burke for assistance with captive bat experimentation and Roberta Swift and Michelle Higashi for field assistance during the effigy trials. We appreciate the assistance of Dr. Tom O'Shea (US Geologic Survey) and his staff in capturing big brown bats for the study and for suggestions for the care of bats in captivity. Dr. Mary Mendonca, Auburn University, provided advice on captive bat care and feeding and Dr. Richard Bowen, Colorado State University, loaned us some of the bat cages used. The State of Hawaii Department of Agriculture sponsored the laboratory portion of this under APHIS Cooperative Agreement \#07-7415-0639 (RA), as QA 1403, approved by the National Wildlife Research Center Institutional Animal Care and Use Committee; field studies were conducted as QA 1331. We appreciate Joy Browning and two anonymous reviewers for providing editorial suggestions. We thank Michael W. Fall for assistance with literature review and manuscript preparation.

Conflict of interest The authors declare that they have no conflict of interest.

\section{References}

Anonymous (1991) Help for migratory bats. Bats magazine 9:3-4 http://www.batcon.org/index.php/media-and-info/bats-archives. html?task=viewArticle\&magArticleID=484. Accessed 11 July 1991

Anonymous (2005) Hydrated lime for coqui and greenhouse frog control. The pesticide label May-June:2-3. http://pestworld. stjohn.hawaii.edu/pat/MayJul05v.2.pdf. Accessed 11 July 2011

Barclay RMR, Thomas DW, Fenton MB (1980) Comparison of methods used for controlling bats in buildings. J Wildl Manag 44:502-506

Beard KH, Price EA, Pitt WC (2009) Biology and impacts of Pacific Island invasive species: Eleutherodactylus coqui, the Coqui frog (Anura: Leptodactylidae). Pac Sci 63:297-316

Bruce RD (1985) An up-and-down procedure for acute toxicity testing. Fundam Appl Toxicol 5:151-157

Campbell EW III, Kraus F (2002) Neotropical frogs in Hawaii: status and management options for an unusual pest. Verteb Pest Conf 20:316-318

Clark DR, LaVal RK, Swineford DM (1978) Dieldrin-induced mortality in an endangered species. Science 199:1357-1359

Gorresen, MP, Bonaccorso FJ, Pinzari CA, Todd CM, MontoyaAiona K, Brinck K (2013) A five year study of Hawaiian hoary bat (Lasiurus cinereus semotus) occupancy on the island of Hawaii. Hawaii Cooperative Studies Unit Tech. Rep. HCSU041, $48 \mathrm{pp}$

HDOA (Hawaii Department of Agriculture, Plant Industry Division) (2002) Label for Use of citric acid anhydrous for control of Caribbean tree frogs. 2 pp. Reproduced by Hawaiian ecosystems at risk project. http://www.ctahr.hawaii.edu/coqui/downloads/ citric\%20acid.pdf]. Accessed 7 July 2011

Jacobs DS (1996) Morphological divergence in an insular bat, Lasiurus cinereus semotus. Funct Ecol 10:622-630

Jacobs DS (1999) The diet of the insectivorous Hawaiian hoary bat (Lasiurus cinereus semotus) in an open and a cluttered habitat. Can J Zool 77:1603-1608

Kaiser B, Burnett K (2006) Economic impacts of E. coqui frogs in Hawaii. Interdicip Environ Rev 8:1-11

Kraus F, Campbell EW III (2002) Human-mediated escalation of a formerly eradicable problem: the invasion of Caribbean frogs in the Hawaiian Islands. Biol Invasions 4:327-332

Kraus F, Campbell EW III, Allison A, Pratt T (1999) Eleutherodactylus frog introductions to Hawaii. Herpetol Rev 30:21-25

Lollar A, Schmidt-French B (2002) Captive care and medical reference for the rehabilitation of insectivorous bats, 2 nd edn. Bat World Publications, Mineral Wells, p 340 
Menard T (2001) Activity patterns of the Hawaiian hoary bat (Lasiurus cinereus semotus) in relation to reproductive time periods. M. S. Thesis, University of Hawaii, Honolulu, $149 \mathrm{pp}$

Mitchell GC (1986) Vampire bat control in Latin America, p 151-164 (Chapter 13) in National Research Council. Ecological knowledge and environmental problem-solving: concepts and case studies. National Academy Press, Washington D.C., 388 pp

Pitt WC, Sin H (2004) Testing citric acid use on plants. Hawaii Landscape, July-August 5/12

Pitt WC, Beard KH, Doratt R (2012) Management of invasive coqui frog populations in Hawaii. Outlooks Pest Manag 23(4):166-169

Ratcliffe JM, Fenton MB, Galef BG Jr (2003) An exception to the rule: common vampire bats do not learn taste aversions. Anim Behav 65:385-389

Rispin A, Podell H, Meyer W (2000) Gender sensitivity of xenobiotics: summary of literature in toxicity testing, Vol. 2. Pages 3-22 in Appendix P-1. The revised up-and-down procedure: a test method for determining the acute oral toxicity of chemicals. National Institute of Environmental Health Sciences, U. S. Public health Service, Washington, D.C. http://www.bvsde. paho.org/bvstox/i/fulltext/udfinal/udfinal.pdf. Accessed $24 \mathrm{Feb}$ 2011
Sample BE, Aplin MS, Efroymsan RA, Suter II GW, Welch CJ (1997) Methods and tools for estimation of the exposure of terrestrial wildlife to contaminants. Final report prepared for the U.S. Department of Energy, Oakridge National Laboratory, Oak Ridge, Tennessee, 148 pp. http://www.esd.ornl.gov/programs/ ecorisk/documents/tm13391.pdf and http://www.esd.ornl.gov/ programs/ecorisk/documents/t13391.pdf. Accessed 30 June 2011

Shump KA Jr, Shump AU (1982) Lasiurus cinereus. Mammalian Species 185:1-5

Tomich PQ (1986) Mammals in Hawaii, 2nd edn. Bishop Museum Press, Honolulu, p 375

Tuttle NC, Beard KH, Al-Chokhachy R (2008) Aerially applied citric acid reduces the density of an invasive frog in Hawaii. USA Wildl Res 35(7):676-683

USEPA (U. S. Environmental Protection Agency) (1992) R.E.D. FACTS: citric acid, EPA-738-F-92-017, Washington, D.C, 3 pp. http://www. epa.gov/oppsrrd1/REDs/factsheets/4024fact.pdf. Accessed 30 June 2011

USFWS (U.S. Fish and Wildlife Service) (1998) Recovery Plan for the Hawaiian Hoary Bat (Lasiurus cinereus semotus). USFWS, Region 1, Portland, Oregon. $50 \mathrm{pp}$

Whitaker JO, Tomich PQ (1983) Food habits of the hoary bat, Lasiurus cinereus from Hawaii. J Mammol 64:151-152 